\title{
Linkage Mapping in a Watermelon Population Segregating for Fusarium Wilt Resistance
}

\author{
Leigh K. Hawkins and Fenny Dane \\ Department of Horticulture, 101 Funchess Hall, Auburn University, Auburn, AL 36849-5408
}

Thomas L. Kubisiak

U.S. Department of Agriculture Forest Service, Southern Institute for Forest Genetics, 23332 Highway

67, Saucier, MS 39574

Billy B. Rhodes

Department of Horticulture, E142 Poole Center, Clemson University, Clemson, SC 29634-0375

Robert L. Jarret

U.S. Department of Agriculture, Agricultural Research Service, 1109 Experiment Street, Griffin, GA 30233

\begin{abstract}
AdDitional INDEX words. Citrullus lanatus, Fusarium oxysporum f. sp. niveum, random amplified polymorphic DNA, simple sequence repeats

Abstract. Isozyme, randomly amplified polymorphic DNA (RAPD), and simple sequence repeats (SSR) markers were used to generate a linkage map in an $F_{2}$ and $F_{3}$ watermelon [Citrullus lanatus (Thumb.) Matsum. \& Nakai] population derived from a cross between the fusarium wilt (Fusarium oxysporum f. sp. niveum) susceptible 'New Hampshire Midget' and resistant PI 296341-FR. A 112.9 cM RAPD-based map consisting of 26 markers spanning two linkage groups was generated with $F_{2}$ data. With $F_{3}$ data, a $139 \mathrm{cM}$ RAPD-based map consisting of 13 markers covering five linkage groups was constructed. Isozyme and SSR markers were unlinked. About $40 \%$ to $48 \%$ of the RAPD markers were significantly skewed from expected Mendelian segregation ratios in both generations. Bulked segregant analysis and single-factor analysis of variance were employed to identify RAPD markers linked to fusarium wilt caused by races 1 and 2 of $F$. oxysporum f. sp. niveum. Current linkage estimates between the resistance trait and the marker loci were too large for effective use in a marker-assisted selection program.
\end{abstract}

The diploid watermelon (Citrullus lanatus; $2 \mathrm{n}=2 \mathrm{x}=22$; Shimotsuma, 1963) suffers from a number of serious fungal, bacterial, and viral diseases that reduce yield and quality (Bruton, 1998; Nagel et al., 1992). One of the most economically important of these is fusarium wilt caused by the soilborne fungus Fusarium oxysporum f.sp. niveum (FON) (Martyn, 1996; Purseglove, 1987). FON has been separated into three pathogenic races: 0, 1, and 2 (Martyn, 1987; Netzer, 1976). Control of this disease relies primarily on use of resistant cultivars and crop rotation. While many commercial cultivars have resistance to races 0 and 1 of the pathogen, the more aggressive race 2 overcomes all cultivars and has great potential for spread in watermelon production areas in the southeastern United States because it can be seedborne (Bruton, 1998; Hopkins et al., 1992; Martyn and Netzer, 1991). Resistance to the various races has been identified in plant accessions from Africa (Dane et al., 1998; Martyn, 1987). A single dominant gene, designated $F_{O}$ - 1 , confers resistance to race 1 of FON in watermelon (Netzer and Weintall, 1980), while resistance to race 2 in PI 296341-FR (Citrullus lanatus var. citroides) is thought to be conferred by a recessive gene with interactions with some minor genes (Martyn and Netzer, 1991; Zhang and Rhodes, 1993).

Variations among the cultivated watermelon are low with respect to isozymes and economically important characteristics and this has hindered construction of a detailed genetic map (Hashizume et al., 1996; Zhang et al., 1994). In a survey of 26

Received for publication 14 August 2000. Accepted for publication 17 Feb. 2001. The cost of publishing this paper was defrayed in part by the payment of page charges. Under postal regulations, this paper therefore must be hereby marked advertisement solely to indicate this fact. allozymic loci in 550 cultivated watermelon accessions, very little variation was found, but significant divergence was detected between cultivated and wild Citrullus Schrad. sp. forms (Navot and Zamir, 1987). Navot et al. (1990) constructed an isozymebased map containing seven linkage groups spanning $354 \mathrm{cM}$ using a backcross population derived from $C$. lanatus $\times C$. colocynthis (L.) Schrad. Hashizume et al. (1996) constructed a $524 \mathrm{cM}$ linkage map spanning 11 linkage groups in a backcross population of a cultivated Japanese $C$. lanatus line and a wild African form. Other cucurbit genomes have been studied more extensively than the Citrullus genome. Genetic linkage maps have been created using molecular, isozymic, morphological, and disease resistance markers in intraspecific cucumber (Cucumis sativus L.) populations (Kennard et al., 1994; Meglic and Staub, 1996), and in intra- and interspecific melon (Cucumis melo L.) populations (Danin-Poleg et al., 1998; Oliver et al., 1998; Wang et al., 1997).

Highly saturated genetic maps facilitate identification of genes controlling both qualitative and quantitative traits of interest (Wang et al., 1998). Molecular markers linked to disease resistance would accelerate the time-honored, though time-consuming method of artificial inoculation, by easing the process of screening large numbers of individual plants to evaluate the introgression of resistance (Wechter et al., 1995). Near-isogenic lines (NILs) and various pooling strategies have a great potential for rapid characterization of a trait of interest (Weising et al., 1995). Bulked segregant analysis (BSA) can be used to simulate a pair of NILs by pooling DNA from a population segregating for a specific trait (Wang et al., 1998). BSA has been used to identify markers linked to genes for disease resistance e.g. fusarium wilt resistance in melon (Cucumis melo, Wechter et al., 1995; 1998). 
Therefore, the objectives of this research were to 1) identify and characterize polymorphic molecular markers in an $\mathrm{F}_{2}$ population as well as $\mathrm{F}_{3}$ lines derived from a cross between the susceptible 'New Hampshire Midget' (NHM) (C. lanatus var. lanatus) and the resistant PI 296341-FR (C. lanatus var. citroides), 2) use these markers to construct a genetic linkage map, and 3) examine the association between the inheritance of specific molecular marker alleles and resistance to race 1 and 2 of FON.

\section{Materials and Methods}

Plant material. The susceptible 'New Hampshire Midget' (female parent) and the resistant PI 296341-FR (Martyn and Netzer, 1991) were used as parents. Individual $F_{1}$ and $F_{2}$ plants were advanced to produce $\mathrm{F}_{3}$ lines.

FusARIUM WILT SCREENING ASSAY. American type culture collection (ATCC) strains of the pathogen Race 1 (ATCC 18467; Armstrong and Armstrong, 1978; Biles and Martyn, 1989) and Race 2 (ATCC 62939; Martyn, 1987)), were used to screen NHM, PI 296341-FR, $\mathrm{F}_{1}$, and $72 \mathrm{~F}_{3}$ lines. Following DNA extraction, eight, 2-week-old seedlings from each line per race were inoculated by root dip in an inoculum of $1 \times 10^{6}$ microconidia $/ \mathrm{mL}$ (Martyn, 1987). The plants were evaluated under greenhouse conditions without supplemental lighting. Individual plants were rated on a scale of 1 to 5 with $1=$ healthy, no evidence of wilt over a 3 -week period, 2 = beginning signs of wilt, $3=$ slightly wilted and stunted plants, $4=$ wilted and stunted, and $5=$ heavily wilted and death of the seedlings (Dane et al., 1998). Disease ratings were conducted over 3 weeks. Crown (stem-root junction) sections of selected plants, both susceptible and resistant, were surface sterilized and plated on quarter-strength potato dextrose agar to verify FON infection (Wechter et al., 1995).

ISOZYME ANALYSIS. Cotyledonary tissue from four of the eight individuals from each of $72 \mathrm{~F}_{3}$ lines $(125 \mathrm{mg} / \mathrm{line})$ was bulked and homogenized by hand in a pre-chilled mortar and pestle with 500 $\mathrm{mL}$ phosphate extraction buffer (HyPure, Isolab, Perkin Elmer, Branchburg, N.J.). Crude extracts were microcentrifuged for 10 min at $14,000 g_{\mathrm{n}}$ in a microcentrifuge (Eppendorf 5415C; Brinkman Instruments, Westbury, N.Y.). Supernatant ( $8.5 \mathrm{~mL}$ per sample) was electrophoresed on a Hypure agarose horizontal isoelectric focusing gel (FS-5080, pH 4-5) using the Multiphor Electrophoresis System (Amersham Pharmacia Biotech, Piscateway, N.J.). Samples were assayed for acid phosphatase [ACP, Enzyme Commission (EC) 31.3.2], aconitase (AK; EC 4.2.1.3), alcohol dehydrogenase (ADH; EC 1.1.1.1), diaphorase (DIA; EC 1.6.99), esterase (EST; EC 3.1.1), glutamate-oxaloacetate transaminase (GOT; EC 2.6.1.1), isocitrate dehydrogenase (IDH; EC 1.1.1.42), malate dehydrogenase (MDH; EC 1.1.1.37), malic enzyme (ME; EC 1.1.1.40), peroxidase(PRX;EC 1.11.1.7), 6-phosphoglucanate dehydrogenase (6-PGD; EC 1.1.1.49), phosphohexose isomerase (PHI; EC 5.3.1.9), shikimic acid dehydrogenase (SKD; EC 1.1.1.25), superoxide dismutase (SOD; EC 1.15.1.1), and triose phosphate isomerase (TPI; EC 5.3.1.1). Gels were stained as described by Wendel and Weeden (1989).

DNA ISOLATION. DNA was extracted from $100 \mathrm{mg}$ freeze-dried leaf material from $98 \mathrm{~F}_{2}$ watermelon plants, and from $500 \mathrm{mg}$ of fresh cotyledon tissue from 2-week-old seedlings of PI 296341$F R, \mathrm{NHM}_{1} \mathrm{~F}_{1}$, and four individuals from each of $72 \mathrm{~F}_{3}$ lines using a modified CTAB extraction technique (Wagner et al., 1992) with additional purification steps (Kubisiak et al., 1997), or using the Phytopure plant DNA extraction kit (Amersham Pharmacia Biotech.).
BULKED SEGREGANT ANALYSIS. Disease resistance rating means were calculated for each $\mathrm{F}_{3}$ line for each race of the pathogen. Data were subjected to analysis of variance (ANOVA) using Proc GLM of SAS and means were separated by Duncan's multiple range test (SAS Inst., Inc., 1996). Two bulked DNA samples were prepared for each race of the pathogen, one resistant bulk $(\mathrm{R})$ and one susceptible bulk (S). Bulked samples consisted of equal volumes of standardized DNA $\left(25 \mathrm{ng} \cdot \mathrm{mL}^{-1}\right)$ from 10 resistant and 10 susceptible lines, respectively.

RAPD ANALYSIS. To identify segregating polymorphisms, one hundred fourteen 10-mer primers from Operon Technologies (Alameda, Calif.) and the University of British Columbia (Vancouver, British Columbia, Canada), along with five 12-mer primers identified by Hashizume et al., (1996) were screened on a panel of DNAs consisting of NHM, PI 296341-FR, $\mathrm{F}_{1}$, and $5 \mathrm{~F}_{2}$ progenies. Primers that amplified bands that were polymorphic between NHM and PI 296341-FR, present in the $\mathrm{F}_{1}$, and present in at least one $F_{2}$ progeny were classified as potentially useful markers.

In the $\mathrm{F}_{3}$ population, three hundred twenty nine 10 -mer primers from Operon Technologies and from the University of British Columbia were screened for their ability to detect polymorphisms between NHM and PI 296341-FR as well as the R and S bulks. Potentially useful polymorphisms were further characterized on each of the individuals from the $\mathrm{F}_{3}$ lines composing the respective bulks.

Polymerase chain reaction (PCR) was performed in a $25 \mu \mathrm{L}$ volume containing $10 \mathrm{~mm}$ Tris- $\mathrm{HCl}, 3.0 \mathrm{~mm} \mathrm{MgCl}_{2}, 10 \mathrm{~mm} \mathrm{KCl}$ ( $\mathrm{pH} 8.3$ ), $0.2 \mathrm{~mm}$ of each nucleotide (Perkin Elmer), 5 pmol 10mer or 12-mer oligonucleotide primers, $10 \mathrm{ng}$ genomic DNA and 1 unit of Amplitaq polymerase (Perkin Elmer). The thermocyclers were programmed as follows: initial denaturation at $94{ }^{\circ} \mathrm{C}$ for 10 min, 35 cycles of $94^{\circ} \mathrm{C}$ for $45 \mathrm{~s}, 36^{\circ} \mathrm{C}$ for $45 \mathrm{~s}$, and $72{ }^{\circ} \mathrm{C}$ for 2 min, followed by a final extension at $72{ }^{\circ} \mathrm{C}$ for $5 \mathrm{~min}$. Amplification products were electrophoresed on $1.2 \%$ agarose gels and detected by staining with ethidium bromide. The gels were photographed under ultraviolet light with Polaroid film 667 (Polaroid Corporation, Cambridge, M.A.). Lambda ( $\lambda$ ) DNA digested with PstI was used as a molecular size marker. Each band was named by the primer used and its size in basepairs (bp): OPF $16_{1600}$ was the $1600 \mathrm{bp}$ band amplified by Operon primer F16.

SSR ANALYSIS. A total of 107 simple sequence repeats (SSR) primers from Jarret et al. (1997, and unpublished results) and Katzir et al. (1996) were screened against the parents and the $F_{1}$ to detect polymorphisms. Analysis was performed on four individuals bulked from each of $72 \mathrm{~F}_{3}$ lines. PCR was performed in a $20 \mu \mathrm{L}$ volume containing $10 \mathrm{~mm}$ Tris- $\mathrm{HCl}, 3.0 \mathrm{~mm} \mathrm{MgCl}_{2}, 10 \mathrm{~mm}$ $\mathrm{KCl}$ (pH 8.3), $0.2 \mathrm{~mm}$ of each nucleotide (Perkin Elmer), $1 \mu \mathrm{M}$ of each primer, $1.6 \%$ bovine serum albumin, $50 \mathrm{ng}$ genomic DNA and 1 unit of Amplitaq polymerase (Perkin Elmer). Thermocyclers were programmed as follows: initial denaturation at $94{ }^{\circ} \mathrm{C}$ for 5 min, 35 cycles of $94^{\circ} \mathrm{C}$ for $1 \mathrm{~min}, 55^{\circ} \mathrm{C}$ for $1 \mathrm{~min}$ and $72^{\circ} \mathrm{C}$ for $2 \mathrm{~min}$, followed by a final extension at $72{ }^{\circ} \mathrm{C}$ for $2 \mathrm{~min}$. The amplified products were separated on a $0.4 \mathrm{~mm}$ thick, $6 \%$ denaturing polyacrylamide gel. For molecular weight size determinations, 25 bp and/or 100 bp DNA ladders (GibcoBRL) were used. The gel was silver-stained using the method of Bassam et al. (1991).

LINKAGE ANALYSIS. Each RAPD band was tested for goodness of fit to the expected 3:1 segregation ratio in the $F_{2}$ or $5: 3$ ratio in the $\mathrm{F}_{3}$ by chi-square analysis $(P<0.01)$. Those markers experiencing segregation distortion were excluded from linkage analy- 
Table 1. Mean fusarium wilt race 1 disease resistance ratings in $\mathrm{F}_{3}$ lines derived from a cross between fusarium wilt-susceptible 'New Hampshire Midget' $x$ resistant PI 296341-FR.

\begin{tabular}{|c|c|c|}
\hline $\mathrm{F}_{3}$ lines & \multicolumn{2}{|c|}{ Mean disease rating } \\
\hline $\mathrm{F}_{3}-2$ & $5.0 \mathrm{a}^{\mathrm{z}}$ & Susceptible \\
\hline $\mathrm{F}_{3}-11, \mathrm{~F}_{3}-126$ & $4.5 \mathrm{ab}$ & Susceptible \\
\hline $\mathrm{F}_{3}-30, \mathrm{~F}_{3}-74$ & $4.3 \mathrm{abc}$ & Susceptible \\
\hline $\mathrm{NHM}, \mathrm{F}_{3}-43, \mathrm{~F}_{3}-86, \mathrm{~F}_{3}-95$ & $4.1 \mathrm{abcd}$ & Susceptible \\
\hline $\mathrm{F}_{3}-123, \mathrm{~F}_{3}-15, \mathrm{~F}_{3}-59, \mathrm{~F}_{3}-67, \mathrm{~F}_{3}-48, \mathrm{~F}_{3}-33, \mathrm{~F}_{3}-105$ & 3.9 abcde & Susceptible \\
\hline $\mathrm{F}_{3}-52, \mathrm{~F}_{3}-41, \mathrm{~F}_{3}-23, \mathrm{~F}_{3}-5, \mathrm{~F}_{3}-51$ & 3.7 bcde & Intermediate \\
\hline$F_{3}-54, F_{3}-9, F_{3}-80, F_{3}-39, F_{3}-71, F_{3}-61, F_{3}-79, F_{3}-121$ & 3.6 bcdef & Intermediate \\
\hline$F_{3}-107, F_{3}-60, F_{3}-25, F_{3}-113, F_{3}-98, F_{3}-111$ & 3.5 bcdefg & Intermediate \\
\hline $\mathrm{F}_{3}-20, \mathrm{~F}_{3}-14, \mathrm{~F}_{3}-16, \mathrm{~F}_{3}-62, \mathrm{~F}_{3}-116, \mathrm{~F}_{3}-29, \mathrm{~F}_{3}-89, \mathrm{~F}_{3}-76$ & 3.3 bcdefgh & Intermediate \\
\hline $\mathrm{F}_{3}-6, \mathrm{~F}_{3}-117, \mathrm{~F}_{3}-70, \mathrm{~F}_{3}-128, \mathrm{~F}_{3}-10, \mathrm{~F}_{3}-45, \mathrm{~F}_{3}-83, \mathrm{~F}_{3}-97$ & 3.1 cdefgh & Intermediate \\
\hline $\mathrm{F}_{3}-110, \mathrm{~F}_{3}-46, \mathrm{~F}_{3}-36, \mathrm{~F}_{3}-77$ & 2.9 defghi & Intermediate \\
\hline $\mathrm{F}_{3}-101, \mathrm{~F}_{3}-55$ & 2.6 efghij & Intermediate \\
\hline $\mathrm{F}_{3}-82, \mathrm{~F}_{3}-99, \mathrm{~F}_{3}-85, \mathrm{~F}_{3}-119$ & 2.4 fghijk & Resistant \\
\hline $\mathrm{F}_{3}-49, \mathrm{~F}_{3}-120, \mathrm{~F}_{3}-102$ & 2.3 ghijk & Resistant \\
\hline $\mathrm{F}_{3}-81, \mathrm{~F}_{3}-38, \mathrm{~F}_{3}-100, \mathrm{~F}_{3}-88$ & $2.1 \mathrm{hijk}$ & Resistant \\
\hline $\mathrm{F}_{3}-19$, PI $296341-F R$ & $1.7 \mathrm{jk}$ & Resistant \\
\hline $\mathrm{F}_{1}$ & $1.4 \mathrm{k}$ & Resistant \\
\hline
\end{tabular}

${ }^{\mathrm{z}}$ Mean separation within column by Duncan's multiple range test, $P<0.05$.

Table 2. Mean fusarium race 2 disease resistance ratings in $\mathrm{F}_{3}$ lines derived from a cross between fusarium wilt-susceptible 'New Hampshire Midget' $\mathrm{X}$ resistant PI 296341-FR.

\begin{tabular}{|c|c|c|}
\hline $\mathrm{F}_{3}$ lines & \multicolumn{2}{|c|}{ Mean disease rating } \\
\hline $\mathrm{NHM}, \mathrm{F}_{3}-2$ & $5.0 \mathrm{a}^{\mathrm{z}}$ & Susceptible \\
\hline $\mathrm{F}_{3}-52$ & $4.8 \mathrm{ab}$ & Susceptible \\
\hline $\mathrm{F}_{3}-43, \mathrm{~F}_{3}-55$ & $4.5 \mathrm{abc}$ & Susceptible \\
\hline $\mathrm{F}_{3}-45, \mathrm{~F}_{3}-37, \mathrm{~F}_{3}-11, \mathrm{~F}_{3}-59, \mathrm{~F}_{3}-61, \mathrm{~F}_{3}-9, \mathrm{~F}_{3}-74$ & $4.4 \mathrm{abcd}$ & Susceptible \\
\hline $\mathrm{F}_{3}-29, \mathrm{~F}_{3}-62, \mathrm{~F}_{3}-80, \mathrm{~F}_{3}-23, \mathrm{~F}_{3}-68$ & 4.3 abcde & Susceptible \\
\hline $\mathrm{F}_{3}-5, \mathrm{~F}_{3}-25, \mathrm{~F}_{3}-86$ & 4.1 abcdef & Intermediate \\
\hline $\mathrm{F}_{3}-16, \mathrm{~F}_{3}-79, \mathrm{~F}_{3}-71, \mathrm{~F}_{3}-15, \mathrm{~F}_{3}-42$ & 4.0 abcdefg & Intermediate \\
\hline $\mathrm{F}_{3}-51, \mathrm{~F}_{3}-48, \mathrm{~F}_{3}-60$ & 3.8 abcdefgh & Intermediate \\
\hline $\mathrm{F}_{3}-95, \mathrm{~F}_{3}-100, \mathrm{~F}_{3}-98, \mathrm{~F}_{3}-54, \mathrm{~F}_{3}-6, \mathrm{~F}_{3}-33, \mathrm{~F}_{3}-46$ & 3.6 abcdefghi & Intermediate \\
\hline $\mathrm{F}_{3}-120, \mathrm{~F}_{3}-116$ & 3.5 bcdefghi & Intermediate \\
\hline $\mathrm{F}_{3}-117, \mathrm{~F}_{3}-67, \mathrm{~F}_{3}-39, \mathrm{~F}_{3}-10, \mathrm{~F}_{3}-99, \mathrm{~F}_{3}-111$ & 3.3 bcdefghij & Intermediate \\
\hline$F_{3}-110, F_{3}-105, F_{3}-101, F_{3}-20, F_{3}-41, F_{3}-97, F_{3}-128, F_{3}-70, F_{3}-81$ & 3.1 cdefghij & Intermediate \\
\hline $\mathrm{F}_{3}-121, \mathrm{~F}_{3}-126, \mathrm{~F}_{3}-77, \mathrm{~F}_{3}-14, \mathrm{~F}_{3}-107, \mathrm{~F}_{3}-76, \mathrm{~F}_{3}-102, \mathrm{~F}_{3}-119, \mathrm{~F}_{3}-38$ & 3.0 defghij & Intermediate \\
\hline $\mathrm{F}_{3}-88, \mathrm{~F}_{3}-85, \mathrm{~F}_{3}-83$ & 2.9 efghij & Intermediate \\
\hline $\mathrm{F}_{3}-30, \mathrm{~F}_{3}-89, \mathrm{~F}_{3}-123, \mathrm{~F}_{3}-82$ & 2.7 fghij & Resistant \\
\hline $\mathrm{F}_{3}-49, \mathrm{~F}_{3}-113$ & 2.6 ghij & Resistant \\
\hline $\mathrm{F}_{3}-17, \mathrm{~F}_{3}-36, \mathrm{~F}_{3}-19$ & 2.5 hij & Resistant \\
\hline PI 296341-FR & $2.3 \mathrm{ij}$ & Resistant \\
\hline $\mathrm{F}_{1}$ & $2.0 \mathrm{j}$ & Resistant \\
\hline
\end{tabular}

${ }^{\mathrm{z} M e a n}$ separation within column by Duncan's multiple range test, $P<0.05$.

ses. The mapping software packages Joinmap v. 2.0 (Stam, 1993; Stam and Van Ooijen, 1995) and MAPMAKER/EXP v. 3.0 (Lander et al., 1987) were used for linkage analysis. Marker orders were determined using MAPMAKER/EXP with LOD $\leq$ 4.0 and recombination fraction $(\theta)=0.3$. Map distances between linked markers were estimated using the Kosambi mapping function (Kosambi, 1944). The software program DrawMap v. 0.9 (Ooijen, 1992) was used to draw the genetic linkage maps.

Association With Resistance. The degree of association between the molecular marker loci and disease resistance data was investigated using single-factor ANOVA (SAS Inst., Inc., 1996), in which the individual marker genotypes were used as class variables. Four individuals per line from each of the susceptible and resistant lines, based on results of Duncan's multiple range test were included in the analyses. A fairly liberal threshold $(P<0.05)$ was chosen in an attempt to lower the type II error rate.

\section{Results}

FusARIUM WILt RESISTANCE ASSAY. Disease rating scores for NHM, PI 296341-FR, $\mathrm{F}_{1}$, and $\mathrm{F}_{3}$ lines, are presented in Tables 1 and 2 , and indicate resistance is controlled by dominant gene action because disease rating scores of the $F_{1}$ were not significantly different from that of PI 296341-FR. Based on mean separation, any $F_{3}$ line with a disease rating $\geq 3.9$ for race 1 was considered susceptible, while any $\mathrm{F}_{3}$ line with disease rating $\leq 2.4$ was considered resistant. All other lines were considered as intermediate (Table 1). Based on this analysis, $15 \mathrm{~F}_{3}$ lines were 
Table 3. Genetic linkage map generated from markers segregating among $\mathrm{F}_{2}$ and $\mathrm{F}_{3}$ individuals derived from a cross between the fusarium wiltsusceptible 'New Hampshire Midget' $x$ fusarium wilt-resistant PI 296341-FR.

\begin{tabular}{|c|c|c|c|c|}
\hline Generation & Linkage group & No of markers & Map distance (cM) & Spacing $(\mathrm{cM})$ \\
\hline \multirow{4}{*}{$\mathrm{F}_{2}$} & 1 & 2 & 14.0 & 14.0 \\
\hline & 2 & 24 & 98.9 & 4.1 \\
\hline & Unlinked & 42 & & \\
\hline & Total & 68 & 112.9 & \\
\hline \multirow{7}{*}{$\mathrm{F}_{3}$} & 1 & 2 & 26.1 & 26.1 \\
\hline & 2 & 5 & 49.6 & 8.2 \\
\hline & 3 & 2 & 20.7 & 20.7 \\
\hline & 4 & 2 & 19.6 & 19.6 \\
\hline & 5 & 2 & 23.0 & 23.0 \\
\hline & Unlinked & 18 & & \\
\hline & Total & 31 & 139.0 & \\
\hline
\end{tabular}

resistant, 41 intermediate, and 12 susceptible to race 1 , and this ratio does not significantly differ from the expected 1:2:1 segregation ratio $\left(\chi^{2}=3.19\right.$, df $\left.=2, P>0.05\right)$. These findings are consistent with the hypothesis of a single dominant gene controlling resistance to race 1 of FON. Similarly, any line with a disease rating $\geq 4.3$ was considered susceptible to race 2 and rating $\leq 2.6$ as resistant. For race 2 , there were 9 resistant, 47 intermediate, and 16 susceptible $\mathrm{F}_{3}$ lines $\left(\chi^{2}=8.03, \mathrm{df}=2, P<0.01\right)$, which differs significantly from the $1: 2: 1$ ratio that would be expected if this trait were controlled by a single dominant gene. $F_{3}$ lines with resistance or susceptibility to FON 1 in general showed resistance or susceptibility, respectively, to FON 2 (Tables 1 and 2).

\section{Mendelian segregation ratios}

IsOzYMES. Bulked $\mathrm{F}_{3}$ samples were found to be monomorphic for the following enzymes: ME, IDH, GOT, ACP, SKD, and $\mathrm{MDH}$. Banding patterns were vague when the gels were stained for 6-PGD, PHI, AK, TPI, ADH, DIA, and SOD. Staining for the enzymes esterase (EST) and peroxidase (PRX) yielded one polymorphic peroxidase locus (PRX-1) and two polymorphic EST loci in this population and Mendelian segregation analysis indicated that the peroxidase $\left(\chi_{\text {Prx-1 }}^{2}=1.3, P>0.05\right)$ and esterase loci $\left(\chi_{\text {Est-3 }}^{2}=1.52 ; \chi_{\text {Est- } 4}^{2}=1.15, P>0.05\right)$ fit a $3: 1$ ratio.

RAPD ANALYSIS. Of the one hundred fourteen 10-merRAPD primers screened, $64 \%$ revealed at least one polymorphic band between the parents, NHM and PI 296341-FR. Two polymorphic bands were on average detected per primer. A total $52.5 \%$ of the markers fit the expected 3:1 Mendelian segregation ratio $(P>$ $0.01)$.

Of the three hundred twenty nine 10-mer primers used in the BSA screen, 70 showed monomorphic patterns, 117 showed polymorphism between the parents but were monomorphic in the bulks, and 31 amplified at least one band that was polymorphic between NHM and PI 296341-FR as well as the bulks. In total, 60 potentially informative markers were identified, which were tested on four individuals from each line that composed the bulks.

SSR ANALYSIS. Of 107 SSR primers screened against the parents and the $F_{1}$, more than half generated no amplification product, 40 were monomorphic and five generated polymorphisms (CL2-070, CL1-006, CL1-06, CL1-20, and CL2-23) under the described reaction conditions. The seven SSR primers specific for Cucumis L. sp (Katzir et al., 1996) generated no amplification product in this Citrullus population. All markers $\left(\chi_{\mathrm{CL2}-070}^{2}=1.15, \mathrm{df}=1 ; \chi_{\mathrm{CL1}-006}^{2}=0.46, \mathrm{df}=2 ; \chi_{\mathrm{CL1} 1-06}^{2}=1.64, \mathrm{df}\right.$ $\left.=2 ; \chi_{\mathrm{CL} 1-20}^{2}=0.11, \mathrm{df}=2 ; \chi_{\mathrm{CL} 2-23}^{2}=0.13, \mathrm{df}=2\right)$ exhibited the expected 3:1 (band absence versus presence, $\mathrm{df}=1$ ) or 1:2:1 segregation ratio $(\mathrm{df}=2)$ in this population $(P>0.05)$.

LiNKAGE MAPPING. Using only the markers that fit the expected Mendelian segregation ratios, at a LOD of 4.0 and a recombination fraction of 0.3 , two linkage groups were detected in the $F_{2}$ using 98 individuals. Group 1 contained two markers and group 2 contained 24 markers (Table 3; Fig. 1). The isozyme and SSR markers were unlinked. A high percentage $(64 \%)$ of the RAPD markers were unlinked. In an attempt to increase genomic coverage and determine whether any specific regions of the genome were experiencing segregation distortion, distorted markers were mapped one marker at a time (Kubisiak et al., 1997), and found to cluster on linkage group 2.

The linkage map in the $\mathrm{F}_{3}$ consisting of five linkage groups containing two to five markers each was generated using the primers that were capable of detecting differences in the bulked samples. Four individuals selected from each of $28 \mathrm{~F}_{3}$ lines,

1

$2 \mathrm{a}$

2
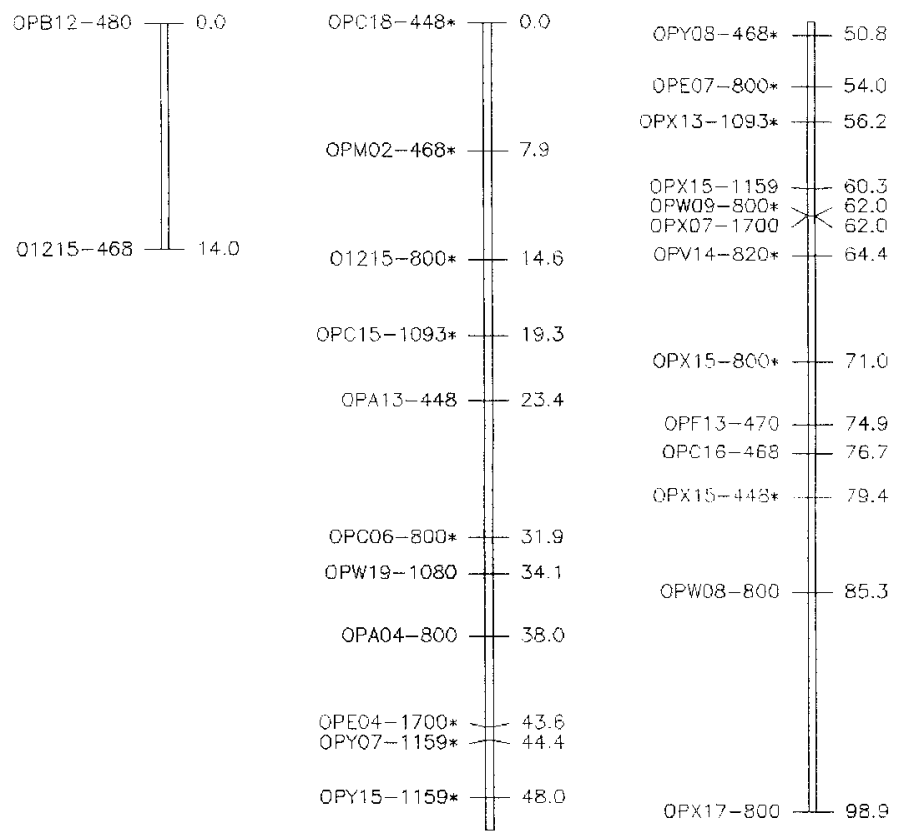

Fig. 1. Linkage map constructed using RAPD marker in $\mathrm{F}_{2}$ watermelon population derived from a cross between the fusarium wilt-susceptible 'New Hampshire Midget' $x$ fusarium wilt-resistant PI 296341-FR (LOD =4). The marker names are given on the left and the position of markers in Kosambi cM is indicated on the right of each linkage group, with * indicating framework marker loci. 
$1 \quad 3 \quad 4 \quad 5$

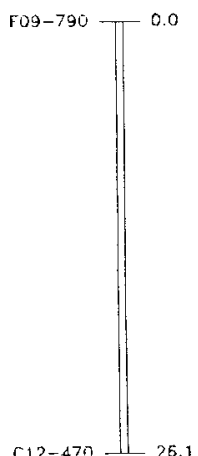

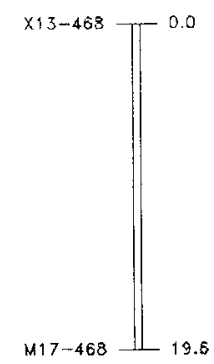

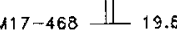
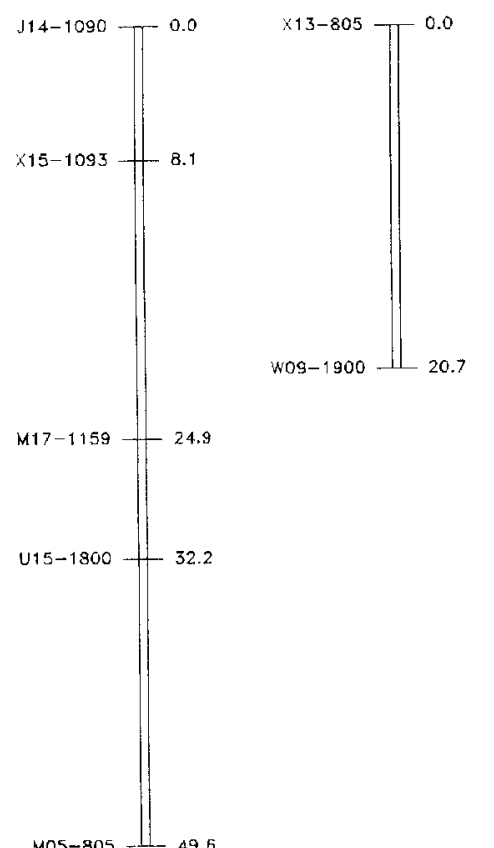

$405-805-11-49.6$

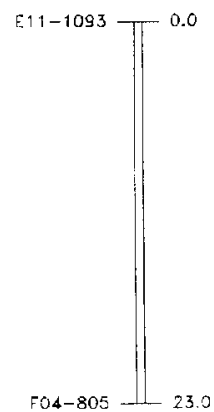

Several RAPD markers segregated in both the $\mathrm{F}_{2}$ and the $\mathrm{F}_{3}$ populations. The marker loci OPY $15_{1159}$, OPX13 1093 , and OPX15 $5_{800}$ segregated in Mendelian fashion in the $\mathrm{F}_{2}$, but showed segregation distortion in the $\mathrm{F}_{3}$. The markers mapped to linkage group 2 in the $F_{2}$ population (Fig. 1), and when mapped one at a time, mapped to regions between markers X15-1093 and M17- 1159 on linkage group 2 in the $\mathrm{F}_{3}$ population (Fig. 2).

Statistical analysis. From the individuals selected from the resistant and susceptible lines for races 1 and 2, several markers were putatively linked to FON 1 and FON 2 resistance by single-factor ANOVA. The resistance trait-marker linkages suggested by single-factor ANOVA were examined by recombination fraction of the resistant and susceptible individuals and marker absence and presence (Table 4). The minimum recombination fraction calculated was 0.33 between race 2 and

Fig. 2. Linkage map constructed using RAPD markers in an $F_{3}$ watermelon population derived from a cross between the fusarium wilt-susceptible 'New Hampshire Midget' $x$ fusarium wilt-resistant PI 296341-FR $(L O D=4)$. The marker names are given on the left and the position of markers in $\mathrm{cM}$ is indicated on the right of each linkage group.

chosen for their response to the fusarium wilt pathogen, were used to generate this map to verify clustering of markers into one linkage group. Sixty polymorphic bands were detected from these 31 primers and used for mapping $112 \mathrm{~F}_{3}$ individuals. Fiftytwo percent of the markers exhibited the expected 5:3 segregation ratio in the $\mathrm{F}_{3}$, and $32.8 \%$ of the RAPD markers were unlinked. Distorted markers were mapped one marker at a time and clustered on linkage group 2. JoinMap and MapMaker produced similar linkages and map orders. marker $\mathrm{C} 12_{470}$. This level of recombination is too great to be advantageous in marker-assisted selection. Visual inspection of band presence and/or absence versus the disease-resistant phenotype confirmed that there was very little to no linkage between the trait and the marker locus.

\section{Discussion}

A molecular marker must generate reliable polymorphisms, be relatively simple to perform and be capable of processing a large number of samples per unit of time in order to be useful for marker assisted selection. Where associations between the marker locus and the trait of interest are tight $(<5 \mathrm{cM})$, marker analysis can be used to increase gain from selection because the frequency

Table 4. Occurrence of marker and resistance phenotype in $\mathrm{F}_{3}$ population derived from a cross between the fusarium wilt-susceptible 'New Hampshire Midget' x resistant PI 296341-FR.

\begin{tabular}{|c|c|c|c|c|c|c|c|c|c|c|c|c|c|}
\hline \multirow[b]{2}{*}{ Trait/marker } & \multirow[b]{2}{*}{$\chi^{2}$} & \multicolumn{2}{|c|}{$\begin{array}{l}\text { Single factor } \\
\text { ANOVA }\end{array}$} & \multirow{2}{*}{$\begin{array}{l}\text { Linkage } \\
\text { group }\end{array}$} & \multicolumn{2}{|c|}{ Parents ${ }^{\mathrm{x}}$} & \multicolumn{7}{|c|}{$\begin{array}{c}\text { Observed } \\
\text { frequencies }\end{array}$} \\
\hline & & $\overline{P>\mathrm{F}^{\mathrm{Z}}}$ & $R^{2 \mathrm{y}}$ & & NHM & PI 296341-FR & $\overline{\mathrm{AR}}$ & $\mathrm{Ar}$ & $\mathrm{aR}$ & ar & AI & aI & $\theta^{v}$ \\
\hline$\overline{\text { FON1 }}$ & & & & & $S$ & $\mathrm{R}$ & & & & & & & \\
\hline $\mathrm{X} 13_{1093}$ & $3.33^{\mathrm{Ns}}$ & 0.018 & 5.68 & Unlinked & $\mathrm{C}$ & A & 17 & 15 & 23 & 4 & 30 & 9 & 0.64 \\
\hline $\mathrm{X} 13_{468}^{1093}$ & $3.33^{\mathrm{Ns}}$ & 0.014 & 5.93 & 4 & A & $\mathrm{C}$ & 26 & 7 & 19 & 10 & 27 & 12 & 0.42 \\
\hline $\mathrm{M} 17_{468}^{468}$ & $1.32^{\mathrm{Ns}}$ & 0.031 & 5.46 & 4 & A & $\mathrm{C}$ & 14 & 11 & 8 & 14 & 26 & 12 & 0.40 \\
\hline FON2 & & & & & S & $\mathrm{R}$ & & & & & & & \\
\hline B $12_{468}$ & $0.02^{\mathrm{NS}}$ & 0.012 & 5.28 & Unlinked & A & $\mathrm{C}$ & 8 & 3 & 10 & 0 & 55 & 6 & 0.62 \\
\hline W19 & $24.61^{*}$ & 0.006 & 8.97 & Unlinked & A & $\mathrm{C}$ & 10 & 2 & 11 & 6 & 62 & 9 & 0.45 \\
\hline $\mathrm{X} 13_{448}^{1080}$ & $17.93^{*}$ & 0.028 & 4.85 & Unlinked & A & $\mathrm{C}$ & 4 & 8 & 11 & 6 & 62 & 9 & 0.45 \\
\hline $\mathrm{C} 12_{470}^{448}$ & $1.62^{\mathrm{NS}}$ & 0.018 & 6.10 & 1 & A & $\mathrm{C}$ & 6 & 4 & 4 & 10 & 41 & 26 & 0.33 \\
\hline
\end{tabular}

${ }^{\mathrm{z}}$ Significance levels determined by F-test based on the single factor ANOVA for each pairwise comparison of trait and marker locus.

yPercentage of phenotypic variation explained by the marker locus based on single-factor ANOVA of marker-trait association.

${ }^{\mathrm{x}} \mathrm{A}=$ band absent, $\mathrm{C}=$ band present, $\mathrm{R}=$ resistant, and $\mathrm{S}=$ susceptible.

${ }^{\mathrm{w}} \mathrm{AR}=$ marker present, resistant; $\mathrm{Ar}=$ marker present, susceptible; $\mathrm{aR}$ marker absent, resistant; ar = marker absent, susceptible; $\mathrm{AI}=$ marker present, intermediate; aI = marker absent, intermediate.

'Recombination fraction.

Ns, ${ }^{*}$ Nonsignificant or significant at $P<0.05$. 
of recombination between the marker and the gene is low (Meglic and Staub, 1996). Sixty-four percent of the RAPD primers and $11.1 \%$ of the SSR primers evaluated in this study were able to detect polymorphisms between NHM and PI 296341-FR under the conditions described. Most of the RAPD markers in linkage group $2(90 \%)$ were derived from PI 296341-FR and absent in NHM. None of the Cucumis specific SSRs defined by Katzir et al. (1996) were able to amplify any regions in this mapping population. Similarly Wang et al. (1997) found that only one of the seven Cucumis SSRs was able to detect polymorphisms in a C. melo population.

In the $\mathrm{F}_{2} 52.5 \%$ of the markers followed the expected $3: 1$ or 1:2:1 Mendelian segregation ratio, and in the $\mathrm{F}_{3}$ population $52 \%$ of the markers followed the expected 5:3 segregation ratio. This level of distortion is higher than that reported for other species, although distortions are common in interspecific and intersubspecific populations (Causse et al., 1994). In a number of genera including Cucumis (Kennard et al., 1994; Perin et al., 1998), Lens Mill., Capsicum L., and Lycopersicon Mill. (Zamir and Tadmor, 1986), the proportion of loci deviating from expected Mendelian segregation ratios is higher in interspecific crosses than in intraspecific crosses. These aberrant segregations may be due to either structural genes or cryptic structural differences between the parents or due to artifactual nongenetic variation, organellar bands or epigenetic interactions (Soltis et al., 1998).

Hashizume et al. (1996) using different Citrullus accessions, was able to construct a map covering 11 linkage groups with 2 to 10 markers each in a backcross population with greater coverage of the genome using 12-mer RAPD primers than has been presented herein. The markers generated by 12-mer RAPD markers in the population investigated in this report are all unlinked. Wang et al. (1997) used a backcross $C$. melo population that was segregating for numerous traits including resistance to Fusarium oxysporum f. sp. melonis. The markers generated by 6 RAPD primers used in that map were randomly distributed among the 20 linkage groups detected and were unlinked to each other in the $C$. melo population. These same RAPD markers were all unlinked in this Citrullus population.

Identification of a marker linked to FON 1 or FON 2 resistance should facilitate the introgression of disease resistance from PI 296341-FR into cultivated watermelon. Only loose linkages were detected by three markers to race 1 , and four markers to race 2 , even though 329 RAPD primers were tested. The markers identified by single-factor ANOVA as linked to resistance to either race 1 or race 2 were all too loosely linked to be advantageous in marker-assisted selection. Identification of markers linked tightly to resistance to either race of FON may have been impeded by lack of high levels of resistance in the $\mathrm{F}_{3}$ lines and use of relatively small sample sizes. Several primers have been identified that are linked to the Fon 2 fusarium wilt resistance gene in melon

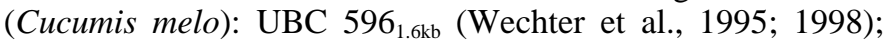

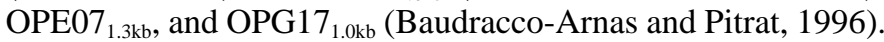
In this population, the bands amplified by primer UBC 596 were not clear, a fragment similar in size to OPE07 $7_{1.3 \mathrm{~kb}}$ was monomorphic, and primer OPG17 did not generate amplification products.

There were several linkage groups that consisted of only two markers and it is clear that more markers are necessary to fill gaps in linkage groups, to integrate linkage groups and cover the entire genome. Over $50 \%$ of RAPD markers and all SSR markers were unlinked. Dominance impairs utility of RAPD markers due to difficulty of detecting linkage between markers in the repulsion phase (Weeden, 1994), however little polymorphism was detected using codominant Citrullus specific SSR primers. Wang et al. (1997) found amplified fragment length polymorphisms to be more efficient at mapping the melon genome than RAPD markers or SSRs. Construction of a detailed genetic map within Citrullus will require not only an interspecific cross but other strategies such as use of watermelon expressed sequence tags (Rhodes and Dane, 1999).

\section{Literature cited}

Armstrong, G.M. and J.K. Armstrong. 1978. Formae speciales and races of Fusarium oxysporum causing wilts of the Cucurbitaceae. Phytopathology 68:19-28.

Bassam, B.J., G. Caetano-Anolles, and P.M.Gresshoff. 1991. Fast and sensitive silver staining of DNA in polyacrylamide gels. Anal. Biochem. 196:80-83.

Baudracco-Arnas, S. and M. Pitrat. 1996. A genetic map of melon (Cucumis melo L.) with RFLP, RAPD, isozyme, disease resistance and morphological markers. Theor. Appl. Genet. 93:57-64.

Biles, C.L. and R.D. Martyn. 1989. Local and systemic resistance induced in watermelons by formae speciales of Fusarium oxysporum. Phytopathology 79:856-860.

Bruton, B.D. 1998. Soilborne disease in Cucurbitaceae: Pathogen virulence and host resistance, p. 143-166. In: J.D. McCreight (ed.). 1998. Cucurbitaceae. ASHS Press, Alexandria, Va.

Causse, T., M. Fulton, Y.G. Cho, S.N. Ahn, J. Chuwongse, K. Wu, J. Xiao, Z. Yu, P.C. Ronald, S.E. Harrington, G. Secont, S.R. McCouch, and S.D. Tanksley. 1994. Saturated molecular map of the rice genome based on an interspecific backcross population. Genetics 138:12511274.

Dane, F., L.K. Hawkins, J.D. Norton, Y.S. Kwon, and Y.H. Om. 1998. New resistance to race 2 of Fusarium oxysporum f. sp. niveum in watermelon. Cucurbit Genet. Coop. Rpt. 21: 37-39.

Danin-Poleg, Y., N. Reis, G. Tzuri, and N. Katzir. 1998. Simple sequence repeats as reference points in Cucumis mapping, p. 349-353. In: J.D. McCreight (ed.). Cucurbitaceae. ASHS Press, Alexandria, Va. Hashizume, T., I. Shimamoto, Y. Harushima, M. Yui, T. Sato, T. Imai, and M. Hirai. 1996. Construction of a linkage map for watermelon (Citrullus lanatus (Thunb.) Matsum. \& Nakai) using random amplified polymorphic DNA (RAPD). Euphytica 90:265-273.

Hopkins, D.L., R.J. Lobinske, and R.P. Larkin. 1992. Selection for Fusarium oxysporum f.sp. niveum race 2 in monocultures of watermelon cultivars resistant to fusarium wilt. Phytopathology 82:290293.

Jarret, R.L., L.C. Merrick, T. Holms, J. Evans, and M.K. Aradhya. 1997. Simple sequence repeats in watermelon (Citrullus lanatus (Thunb.) Matsum. \& Nakai). Genome 40:433-441.

Katzir, N., Y. Danin-Poleg, G. Tzuri, Z. Karchi, U. Lavi, and P.B. Cregan. 1996. Length polymorphism and homologies of microsatellites in several Cucurbitaceae species. Theor. Appl. Genet. 93:1282-1290.

Kennard, W.C., K. Poetter, A. Dijkhuizen, V. Meglic, J.E. Staub, and M. J. Havey. 1994. Linkages among RFLP, RAPD, isozyme, diseaseresistance, and morphological markers in narrow and wide crosses of cucumber. Theor. Appl. Genet. 89:42-48.

Kosambi, D.D. 1944. The estimation of map distances from recombination values. Ann. Eugenics 12:172-175.

Kubisiak, T.L., F.V. Hebard, C.D. Nelson, J. Zhang, R. Bernatzky, H. Huang, S.L. Anagnostakis, and R.L. Doudrick. 1997. Molecular mapping of resistance to blight in an interspecific cross in the genus Castanea. Phytopathology 87:751-759.

Lander, E.S., P. Green, J. Abrahamson, A. Barlow, M.J. Daly, S.E. Lincoln, and L. Newburg. 1987. MAPMAKER: An interactive computer package for constructing primary genetic linkage maps with experimental and natural populations. Genomics 1:174-181.

Martyn, R.D. 1987. Fusarium oxysporum f. sp. niveum race 2: A highly aggressive race new to the United States. Plant Dis. 71:233-236.

Martyn, R.D. 1996. Fusarium wilt of watermelon, p. 13-14. In: T.A. 
Zitter, D.L. Hopkins, and C.E. Thomas (eds.). Compendium of Cucurbit Diseases. APS Press, St. Paul, Minn.

Martyn, R.D. and D. Netzer. 1991. Resistance to races 0, 1, and 2 of fusarium wilt of watermelon in Citrullus sp. PI-296341-FR. HortScience 26:429-432.

Meglic, V. and J.E. Staub. 1996. Inheritance and linkage relationships of isozyme and morphological loci in cucumber (Cucumis sativus L.). Theor. Appl. Genet. 92:865-872.

Nagel, D.H., P. Harris, and F. Killebrew. 1992. Commercial production of watermelon in Mississippi. Miss. State Univ. Coop. Ext. Serv., Starkville.

Navot, N., M. Sarfatti, and D. Zamir. 1990. Linkage relationships of genes affecting bitterness and flesh color in watermelon. J. Hered. 81:162-165.

Navot, N. and D. Zamir. 1987. Isozyme and seed protein phylogeny of the genus Citrullus (Cucurbitaceae). Plant Systematics and Evolution 156:61-67.

Netzer, D. 1976. Physiological races and soil population level of fusarium wilt of watermelon. Phytoparasitica 3:131-136.

Netzer, D. and C. Weintall. 1980. Inheritance of resistance in watermelon to race 1 of Fusarium oxysporum f.sp. niveum. Plant Dis. 64: 853-854.

Oliver, M., J. García-Mas, A.I. López, H. Gómez-Paniagua, and M. Carmen de Vicente. 1998. Toward a sturdy genetic map of melon (Cucumis melo L.), p. 362-364. In: J.E. McCreight (ed.). Cucurbitaceae. ASHS Press, Alexandria, Va.

Ooijen, J.W. 1992. DrawMap, version 0.9. Centre for Plant Breeding and Reproduction Research, Wageningen, The Netherlands.

Perin, C., L. Hagen, C. Dogimont, V. De Conto, and M. Pitrat. 1998. Construction of genetic map of melon with molecular markers and horticultural traits, p. 370-376. In: J.D. McCreight (ed.). Cucurbitaceae. ASHS Press, Alexandria, Va.

Purseglove, J.W. 1987. Tropical crops: Dicotyledons. Wiley, New York. Rhodes, B. and F. Dane. 1999. Gene list for watermelon. Cucurbit Genet. Coop. Rpt. 22:61-77.

SAS Institute, Inc. 1996. SAS system for Windows. SAS Inst., Inc., Cary, N.C.

Shimotsuma, M. 1963. Cytogenetic and evolutionary studies in the genus Citrullus. Seiken Jiho 15:24-34.

Soltis, D.E., P.S. Soltis, and J.J. Doyle. 1998. Molecular systematics of plants II. DNA sequencing. Kluwer Academic Publishers, Norwell, Miss.

Stam, P. 1993. Construction of integrated genetic linkage maps by means of a new computer package: JoinMap. Plant J. 3:739-744.

Stam, P. and J.W. Van Ooijen. 1995. JoinMap ${ }^{\mathrm{TM}}$ version 2.0: Software for the calculation of genetic linkage maps. Centre for Plant Breeding and Reproduction Research, Wageningen, The Netherlands.

Wagner, H., W.E. Weber, and G. Wricke. 1992. Estimating linkage relationships of isozyme markers and morphological markers in sugar beet (Beta vulgaris L.) including families with distorted segregations. Plant Breeding 108:89-96.

Wang, Y.H., C.E. Thomas, and R.A. Dean. 1997. A genetic map of melon (Cucumis melo L.) based on amplified fragment length polymorphism (AFLP) markers. Theor. Appl. Genet. 95:791-798.

Wang, Y.H., C.E. Thomas, and R.A. Dean. 1998. Genome mapping of melon (Cucumis melo L.) for localizing disease resistance genes, $\mathrm{p}$. 354-361. In: J.D. McCreight (ed.). Cucurbitaceae. ASHS Press, Alexandria, Va.

Wechter, W.P., C.E. Thomas, and R. Dean. 1998. Development of sequence-specific primers that amplify a $1.5 \mathrm{~kb}$ DNA marker from race 1 fusarium wilt resistance in Cucumis melo L. HortScience 33:291-292.

Wechter, W.P., M.P. Whitehead, C.E. Thomas, and R.A. Dean. 1995. Identification of a randomly amplified polymorphic DNA marker linked to the Fom 2 fusarium wilt resistance gene in muskmelon MR1. Phytopathology 85:1245-1249.

Weeden, N.F. 1994. Approaches to mapping in horticultural crops, p. 57-68. In: P.M. Gresshoff (ed.). Plant genome analysis. CRC Press, Boca Raton, Fla.

Weising, K., H. Nybom, K. Wolff, and W. Meyer. 1995. DNA Fingerprinting in plants and fungi. CRC Press, Boca Raton, Fla.

Wendel, J.F. and N.F. Weeden. 1989. Visualization and interpretation of plant isozymes, p. 5-45. In: D.E. Soltis and P.S. Soltis (eds.). Isozymes in plant biology. vol. 4. Dioscorides Press, Portland, Ore.

Zamir, D. and Y. Tadmor. 1986. Unequal segregation of nuclear genes in plants. Bot. Gaz. 147:355-358.

Zhang, X.P. and B.B. Rhodes. 1993. Inheritance of resistance to races 0 , 1, and 2 Fusarium oxysporum f. sp. niveum in watermelon (Citrullus sp. PI 296341). Cucurbit Genet. Coop. Rpt 16:77-78.

Zhang, X.P., B.B. Rhodes, and H. Skorupska. 1994. RAPD molecular markers in watermelon. Cucurbit Genet. Coop. Rpt. 17:116-119. 